\title{
Physiological responses, water consumption, and feeding behaviour of lamb breeds fed diets containing different proportions of concentrate
}

\author{
Anderson Lopes Pereira | Michelle de Oliveira Maia Parente ${ }^{\text {(iD }}$ | Anderson de Moura Zanine ${ }^{\text {iD }}$ |

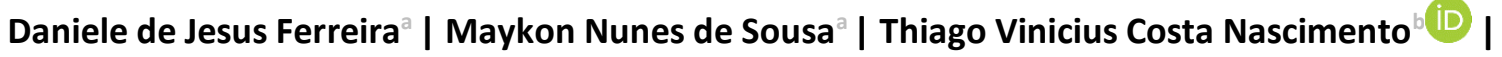 \\ Miguel Arcanjo Moreira Filho | Nítalo André Farias Machado* iD | Anny Graycy Vasconcelos de \\ Oliveira Lima $^{\text {iD | Hyanne Costa Lima }}$ | Henrique Nunes Parente
}

aCenter of Environment and Agriculture Science, Federal University of Maranhão, Chapadinha, 65500-000, Maranhão, Brazil.

${ }^{b}$ Veterinary Medicine Nucleum of Sertão, Federal University of Sergipe, Nossa Senhora da Glória, Sergipe, 49680-000, Brazil.

cDepartment of Animal Science, Federal University of Piauí, Bom Jesus, 64049-550, Piauí, Brazil.

*Corresponding author: nfariasmachado@gmail.com

\begin{abstract}
The use of adapted breeds, such as Santa Inês, is of paramount importance for regions with high temperatures because they develop efficient mechanisms for heat dissipation. Furthermore, some breeds have physiological adaptations, such as more efficient mechanisms for the digestion of fibrous foods (e.g. Rabo Largo), which can reduce the harmful effects of semiarid environments. We studied the ingestive behaviour, water consumption, and physiological parameters during feeding of two native sheep breeds fed diets containing high (700 g/kg DM; HC diet) or low (300 g/kg DM; LC diet) percentages of concentrates, based on dry matter (DM). A total of 40 uncastrated male lambs (20 Rabo Largo [breed 1] and 20 Santa Inês [breed 2], with an average body weight of $16.68 \pm 2.78 \mathrm{~kg}$, and $19.29 \mathrm{~kg} \pm 3.28 \mathrm{~kg}$, respectively), were distributed in a randomised block design in a two-by-two factorial scheme (breeds $\times$ diets) with 10 repetitions. Santa Inês lambs consumed and ruminated DM $(P=0.029$ for both) and neutral detergent fibre (NDF; $P=0.001$ and $P=0.004$, respectively) more efficiently than RaboLargo lambs, while the latter showed an increase in respiratory rate $(+19$ breaths $/ \mathrm{min})$ and rectal temperature $\left(+1.3^{\circ} \mathrm{C}\right)$ compared to the Santa Inês lambs $(P=0.001)$. The HC diet negatively affected $(P<0.05)$ the feeding behaviour of the animals, reflecting the higher $(P<0.05)$ water consumption. The results showed that diets rich in concentrate negatively affected the thermoregulation of lambs. Santa Inês have greater feed and thermoregulatory efficiency than Rabo Largo lambs under conditions of heat stress in the feedlot.
\end{abstract}

Keywords: animal welfare, bioclimatology, efficiencies, respiratory rate

\section{Introduction}

Global warming has resulted in increased public concern about the adaptation of animals to heat (Silva et al 2015), since weather conditions can interfere with physiological parameters and animal behaviour (Santos et al 2019). In addition to being a serious animal welfare problem, thermal stress can lead to losses in profitability in animal production (Maurya et al 2019; Machado et al 2021a).

Brazil is a continental country that is highly suited to agricultural production, and one of the most promising production chains in recent years is sheep farming. Currently, the Brazilian sheep herd holds approximately 19.7 million head, $68.5 \%$ of which are concentrated in the northeast region of the country (IBGE 2020) which is historically marked by a high environmental thermal load and water scarcity (Machado et al 2021b).
Small ruminants express their ingestive behaviour through metabolic changes promoted by the amount of nutrients ingested because they readily adapt to different feeding, handling, and environmental conditions (Machado et al 2020). Thus, the evaluation of ingestive behaviour is important for regulation and adjustment in the nutritional management of animals and understanding the feeding habits of ruminants (Perazzo et al 2017).

Adapted breeds are essential, as they are efficient in the heat dissipation process in hot regions, such as the Northeast of Brazil. Among the sheep commonly most found in Northeastern Brazil, Santa Inês has a high degree of adaptability to semi-arid conditions (Santos et al 2006). However, Rabo Largo sheep stand out among the exploited naturalised breeds mainly in the Northeast, with fat deposition on the tail as a striking characteristic (McManus et al 2020). 
Fat-tailed sheep, such as Rabo Largo, have physiological adaptations that allow them to be more rustic and endure seasonalities in food supply and quality in semiarid environments because they have an efficient digestive mechanism for maximum use of fibre as well as the ability to store energy reserve in their tails (Wilkes et al 2012). However, the latter characteristic can reduce thermoregulatory capacity due to the thermal insulation properties of the fat (Machado et al 2020a).

This study aimed to evaluate ingestive behaviour, water consumption, and physiological parameters during the feeding of two native sheep breeds (Santa Inês and Rabo Largo), fed diets formulated with different levels of concentrates in their composition.

\section{Materials and Methods}

\subsection{Ethical considerations and study location}

The study was conducted at the Federal University of Maranhão, Chapadinha, MA, Brazil $\left(03^{\circ} 44^{\prime} 26^{\prime \prime}\right.$ S, 432 $21^{\prime} 33^{\prime \prime}$ $\mathrm{W}$, and $100 \mathrm{~m}$ altitude), in strict accordance with the recommendations of the Guide for the Care and Use of Agricultural Animals in Research and Teaching and was approved by the Committee on the Ethics of Animal Experiments of the Federal University of Maranhão, Maranhão, Brazil (Protocol Number 23115.006806/2017-76).

\subsection{Animals, housing and treatments}

Forty unecastradet male lambs consisting of twenty Rabo Largo, and twenty Santa Inês with initial average body weights of $16.68 \pm 2.78 \mathrm{~kg}$ and $19.29 \mathrm{~kg} \pm 3.28 \mathrm{~kg}$ respectively, and an average age of 5 months were used in the study. The lambs were housed in individual stalls $(1.3$ by $2.5 \mathrm{~m}$ ) with concrete floors, individually equipped with saltshakers, water buckets, and feed troughs for 58 days.

The lambs underwent an adaptive period of nine days. During this time, all animals were treated against internal and external parasites with Moxidectina (Cydectin, Fort Dodge Animal Health, Campinas, SP, Brazil). Lambs received water and mineral salt ad libitum and were fed twice daily 09:00 and 16:00). The feed refusals were collected and weighed daily, and the amount of feed offered was adjusted to allow for $10 \%$ refusal (Parente et al 2020).

Four experimental treatments were evaluated using the Rabo Largo or Santa Ines lambs, and diets containing high (700 g/kg DM; HC diet) or low (300 g/kg DM; LC diet) concentrate levels (Table 1). The experimental diets were based on Tifton-85 hay (Cynodon spp.), ground corn, and soybean meal, and were formulated according to the NRC (2007) guidelines for an average daily gain (ADG) of $150 \mathrm{~g} /$ day to LC diet and $200 \mathrm{~g} /$ day for the HC diet.

Table 1 Chemical composition of experimental diets.

\begin{tabular}{|c|c|c|}
\hline \multirow{2}{*}{ Ingredients, in g/Kg DM } & \multicolumn{2}{|c|}{ Diets $^{2}$} \\
\hline & $\mathrm{HC}$ diet & LC diet \\
\hline Tifton-85 hay & 300.00 & 700.00 \\
\hline Corn grounded & 542.50 & 141.90 \\
\hline Soybean meal & 100.00 & 100.40 \\
\hline Wheat meal & 40.50 & 40.70 \\
\hline Limestone & 8.10 & 8.00 \\
\hline Mineral Salt ${ }^{1}$ & 8.90 & 8.90 \\
\hline \multicolumn{3}{|l|}{ Chemical composition } \\
\hline Dry matter & 857.80 & 857.10 \\
\hline Crude protein & 127.07 & 107.12 \\
\hline Acid Detergent Fibre & 228.66 & 354.09 \\
\hline Neutral Detergent Fibre & 396.11 & 638.64 \\
\hline Ethereal Extract & 43.70 & 26.64 \\
\hline Organic matter & 940.60 & 922.20 \\
\hline Ash & 59.39 & 77.77 \\
\hline Non-Fibrous Carbohydrate & 373.73 & 149.83 \\
\hline Total Carbohydrate & 769.84 & 788.47 \\
\hline Metabolic Energy (Kcal/kg) & 2.55 & 2.21 \\
\hline
\end{tabular}

${ }^{1}$ Composition: Ca 13,4\%, P 7,5\%, Mg 1\%, S 7\%, Cl 21,8\%, Na 14,5\%, Mn 1100 mg/kg, Fe 500 mg/kg, Zn 4600 mg/kg, Cu 300 mg/kg, Co 40 $\mathrm{mg} / \mathrm{kg}, 155 \mathrm{mg} / \mathrm{kg}$, Se $30 \mathrm{mg} / \mathrm{kg}$. ${ }^{2} \mathrm{HC}$ diet = diet containing high percentage of concentrate $(700 \mathrm{~g} / \mathrm{kg} \mathrm{DM})$ and LC diet = diet containing low percentage of concentrate ( $300 \mathrm{~g} / \mathrm{kg} \mathrm{DM})$ 


\subsection{Experimental procedure}

Samples of ingredients, diets, and refusals were collected, weighed, and identified. After were homogenisation, the samples were pre-dried in a forced-air ventilation oven at $55^{\circ} \mathrm{C}$ for $72 \mathrm{~h}$, ground in a Wiley knife mill (Marconi, Piracicaba, SP, Brazil) with a sieve size of $1 \mathrm{~mm}$, and subjected to analyses to determine the dry matter (DM; method 967.01), ash (method 942.05), crude protein (CP; method 968.06), and ether extract (EE; method 954.05) contents (AOAC 1990).

Neutral detergent fibre (NDF) and acid detergent fibre (ADF) were determined according to Van Soest et al (1991), with changes proposed by Detmann et al (2012), using an autoclave. The non-fiber carbohydrates (NFC) were determined by the equation calculated: NFC (\%) $=100-(\% \mathrm{CP}$ $+\% \mathrm{EE}+\%$ Ash $+\% \mathrm{NDF}$ ). Total carbohydrates (TC) were obtained using the equation TC (\%) $=\% \mathrm{CP}+\% \mathrm{EE}+\%$ Ash, according to Sniffen et al. (1992). Total digestible nutrients (TDN) were calculated by the equation: TDN = digestible CP + (digestible EE $\times 2.25$ ) + digestible NDF + digestible NFC. The metabolizable energy (ME) of each diet was calculated according to NRC (2007).

\subsection{Ingestive behaviour and water intake}

Dry matter (DMI) and neutral detergent fibre (NDFI) intake were calculated as the difference between the amount of diet supplied and the refusals (Table 2). Between the $20^{\text {th }}$ and $41^{\text {st }}$ days of the experimental period, the animal's activities were observed and recorded by two trained evaluators for feeding, rumination, and idling activities (Bürger et al 2000) at 5 min intervals for $24 \mathrm{~h}$ according the method of Johnson and Combs (1991).

Total chewing time was documented during three rumination periods throughout the day, between 11:00 and 13:00, 15:00 and 17:00 and, 19:00 and 21:00. The number of chews per ruminal bolus and the time spent ruminating on each bolus (seconds/bolus) were determined using a digital timer as described by Carvalho et al (2011). The number of ruminated boli (BOL), chewing time per bolus (CTPB), total number of chew (NTC), and the number of chews per bolus (NCPB) were determined according to Polli et al (1996).

Feeding and rumination efficiency were obtained according to Azevedo et al (2013), using the following equations: DM feeding efficiency (g DM/day) = dry matter intake/feeding time (hours/day), and NDF feeding efficiency (g NDF/hour) $=$ neutral detergent fibre intake/feeding time (hours/day).

DM rumination efficiency $(\mathrm{g} M S / \mathrm{h})=$ dry matter intake/rumination time (hours/day), and NDF rumination efficiency (g NDF/hour) $=$ neutral detergent fiber intake/rumination time (hours/day). Total chewing time = feeding time + rumination time (hours/day).

Water intake (Wl, $\mathrm{kg} /$ day) was determined based on the feed offered, feed refused, and water evaporated (Machado et al 2020a). The water intake from feed (1), a total of water intake (2), the ratio between water intake and dry matter intake (3), and the ratio between the total of water intake and dry matter intake (4) were calculated by the following equations:

$$
\begin{gathered}
\mathrm{WFI}=\mathrm{DMI} \times((1000-\mathrm{DM}) / 100) \\
\mathrm{TWI}=\mathrm{WI}+\mathrm{WFI} \\
\text { RWDM }=\text { WI } / \text { DMI } \\
\text { RTWDM }=\mathrm{TWI} / \mathrm{DMI}
\end{gathered}
$$

where: WFI is the intake from feed (kg); DMI is the dry matter intake (g); TWI is the total of water intake ( $\mathrm{kg})$, RWDM is the ratio between water intake and dry matter intake $(\mathrm{kg} / \mathrm{kg})$, and RTWDM is the ratio between the total of water intake and dry matter intake $(\mathrm{kg} / \mathrm{kg})$.

\subsection{Microclimate assessment}

Temperature $\left(T A,{ }^{\circ} \mathrm{C}\right)$, relative humidity $(\mathrm{RH}, \%)$, black globe temperature $\left(B G T,{ }^{\circ} \mathrm{C}\right)$, and wind speed $(\mathrm{WS}, \mathrm{m} / \mathrm{s}$ ) were recorded at 6:00, 10:00, 14:00 and, 18:00. The TA and RH were measured using two thermo-hygrometers (HOBO U1212, São José dos Campos, SP, Brazil) spatially distributed in the experimental shed at a height of $1.20 \mathrm{~m}$ as detailed by Santos et al (2019).

WS was measured using a digital thermo-anemometer (TAFR-180, Sao Paulo, Brazil) and BGT using a globe thermometer (WBGT8778, ASKO ${ }^{\circledR}$, San Leopoldo, Brazil). The thermal profile of the microclimate in the shed was measured by enthalpy (5), radiant heat load (6), and black globe temperature and humidity index using equations (7) according to Rodrigues et al (2011), Esmay (1969), and Buffington et al (1981), respectively.

$$
\begin{gathered}
H=1.006 . T A+\frac{U R}{P b} \cdot 10^{7.5 T A(237.3+T A)^{-1}} \cdot(71.28+0.052 T A) \\
R H L=5.67 \times 10^{-8}\left(100 \sqrt{2.51 \sqrt{W S(B G T-T A)+\left(B G T \times 100^{-14}\right.}}\right)^{4} \\
B G H I=B G T+0.36 \times D p t+41.5
\end{gathered}
$$

where: $\mathrm{H}$ is the enthalpy comfort index ( $\mathrm{Kj} / \mathrm{Kg}$ dry air); $\mathrm{TA}$ is the air temperature $\left({ }^{\circ} \mathrm{C}\right) ; \mathrm{RH}$ is the relative humidity (\%); $\mathrm{BP}$ is local barometric pressure $(\mathrm{mmHg}) ; \mathrm{RHL}$ is the radiant heat load $\left(\mathrm{W} / \mathrm{m}^{2}\right) ; \mathrm{BGHI}$ is the black globe temperature and humidity index, Dpt is the dewpoint temperature $\left({ }^{\circ} \mathrm{C}\right), \mathrm{WS}$ is the wind speed $(\mathrm{m} / \mathrm{s})$, and BGT is the black globe temperature $\left({ }^{\circ} \mathrm{C}\right)$. 


\subsection{Physiological parameters}

From the $42^{\text {nd }}$ to the $55^{\text {th }}$ days of the experimental period, the rectal temperature, respiratory rate, and skin temperature of the animals were determined. The rectal temperature $\left({ }^{\circ} \mathrm{C}\right)$ was measured using a digital clinical thermometer (rigid digital thermometer MC-245, OMRON). The respiratory rate (breaths/min) was obtained by experts observing the flank for $15 \mathrm{~s}$ (Machado et al 2021) with an infrared thermometer (Akrom KR380, Porto Alegre, RS, Brazil), at a distance of $0.50 \mathrm{~cm}$ between the animal and observer. The temperatures of the muzzle, forehead, flank, and base of the tail were obtained. Skin temperature was calculated using the arithmetic mean of these body regions (Santos et al 2019).

\subsection{Statistical analysis}

A randomised complete block design was used in a $2 \times$ 2 factorial ( 2 diets $\times 2$ breeds) scheme, with 10 repetitions. The blocks were defined according to the weight of the lambs at the beginning of the experiment. Data residues were checked for normality using the SAS UNIVARIATE procedure (SAS Inst. Inc., Cary, NC, USA), followed by ANOVA using the MIXED procedure and comparison of the means by the Tukey test $(P<0.05)$.

The statistical model used for intake and animal behavior was: $Y_{i j}=\mu+D_{i}+B_{j}+(D B)_{i j}+\varepsilon_{i j}$, where: $Y_{i j}$ : was the observed value; $\mu$ : was the overall mean; $D_{i}$ : was the effect of the ratio of concentrate in the diets; $B_{j}$ : was the effect of the breed; $(D B)_{i j}$ : was the effect of interaction between diets and breed; $\varepsilon$ ij: was the effect of experimental error.

The physiological parameter data were analysed as repeated measures over time using the mathematical model: $Y_{j \mathrm{jk}}=\mu+D_{i}+B_{j}+T_{k}+(D B)_{i j}+(D T)_{i k}+(B T)_{j k}+\varepsilon_{i j k}$, where: $Y_{i j}:$ was the observed value; $\mu$ : was the overall mean; $D_{i}$ : was the effect of the ratio of concentrate in the diets; $B_{j}$ : was the effect of the breed; $T_{k}$ : was the effect of collection time; (DB) $)_{i j}$ : was the effect of interaction between diets and breed; (DT) $)_{i k}$ : was the effect of interaction between diets and collection time; $(\mathrm{BT})_{\mathrm{jk}}$ was the effect of interaction between breed and collection time; $\varepsilon_{\mathrm{ij}}$ : was the effect of experimental error.

\section{Results}

Santa Inês sheep showed a higher consumption of DM and NDFI, but there were no significant differences in DM and NDFI consumption as a function of the body weight between the breeds (Table 2). Regarding the evaluated diets, the $\mathrm{HC}$ diet increased the intake of DM and reduced the NDFI intake in animals.

Table 3 shows the averages of the micrometeorological variables recorded at the time of collecting the physiological parameters of the animals. The highest thermal load occurred between 10:00 and 14:00, coinciding with the higher incidence of sunlight.

Santa Inês lambs showed higher intakes of water from feed $(P=0.03)$ than Rabo Largo lambs. The HC diet increased $(P<0.05)$ water intake, water intake from feed, and total water intake. We did not observe, effect $(P>0.05)$ of the interaction between diet and breed on the time spent on ingestive activities. The $\mathrm{HC}$ diet increased the time spent with idling, also reduced $(P<0.05)$ the time spent feeding and ruminating, and the total chewing time (Table 4).

Santa Inês lambs showed better feed and rumination efficiency of DM and NDF in the diets $(P<0.05)$ than Rabo Largo lambs. The HC diet increased DM feeding and rumination efficiencies, but did not affect $(P>0.05)$ the interaction between diets and breeds for the time spent on ingestive activities (Table 4).

Table 2 Dry matter intake (DMI), Neutral Detergent Fibre (NDFI) intake, and ratio between intakes and body weight from lamb's breeds fed with experimental diets.

\begin{tabular}{|c|c|c|c|c|c|}
\hline \multirow{2}{*}{ Item } & \multirow{2}{*}{ Breeds } & \multicolumn{2}{|c|}{ Diets $^{1}$} & \multirow{2}{*}{ Means } & \multirow{2}{*}{ SEM } \\
\hline & & $\mathrm{HC}$ diet & LC diet & & \\
\hline \multirow{3}{*}{ DMI (g) } & Rabo Largo & $850.36^{\mathrm{Ba}}$ & $440.99^{\mathrm{Bb}}$ & $645.67^{B}$ & \\
\hline & Santa Inês & $893.73^{\mathrm{Aa}}$ & $692.69^{A b}$ & $793.21^{\mathrm{A}}$ & 42.710 \\
\hline & Means & $872.04^{a}$ & $566.8^{4 b}$ & & \\
\hline \multirow{3}{*}{ DMI (\% BW) } & Rabo Largo & $3.38^{\mathrm{Aa}}$ & $2.51^{\mathrm{Bb}}$ & $2.95^{\mathrm{A}}$ & \\
\hline & Santa Inês & $3.13^{\mathrm{Aa}}$ & 2.99 Аа & $3.06^{A}$ & 0.096 \\
\hline & Means & $3.26^{a}$ & $2.75^{b}$ & & \\
\hline \multirow{3}{*}{ NDFI (g) } & Rabo Largo & $300.13^{\mathrm{Aa}}$ & $264.70^{\mathrm{Ba}}$ & $282.42^{B}$ & \\
\hline & Santa Inês & $305.27^{\mathrm{Ab}}$ & $416.55^{\mathrm{Aa}}$ & $360.91^{A}$ & 16.365 \\
\hline & Means & $302.70^{\mathrm{a}}$ & $340.63^{a}$ & & \\
\hline \multirow{3}{*}{ NDFI (\% BW) } & Rabo Largo & $1.20^{\mathrm{Ab}}$ & $1.52 \mathrm{~B}^{\mathrm{a}}$ & $1.36^{\mathrm{A}}$ & \\
\hline & Santa Inês & $1.07^{\mathrm{Ab}}$ & $1.79 A^{a}$ & $1.43^{\mathrm{A}}$ & 0.065 \\
\hline & Means & $1.13^{b}$ & $1.66^{a}$ & & \\
\hline
\end{tabular}

Averages followed by different letters on the same line, upper case for the breed factor and lower case for the diet factor, did not differ by the Tukey test at $5 \%(P<0.05)$. SEM standard error of means. ${ }^{1} \mathrm{HC}$ diet $=$ diet containing high percentage of concentrate $(700 \mathrm{~g} / \mathrm{kg} \mathrm{DM})$ and $\mathrm{LC}$ diet $=$ diet containing low percentage of concentrate $(300 \mathrm{~g} / \mathrm{kg} \mathrm{DM})$ 
Table 3 Average of climatic variables recorded at the time of analysis of physiological parameters from lambs fed with diets containing high (HC) and low (LC) concentrate.

\begin{tabular}{|c|c|c|c|c|}
\hline \multirow{2}{*}{ Environmental Parameters } & \multicolumn{4}{|c|}{ Hours } \\
\hline & 6 a.m. & 10 a.m. & 2 p.m. & 6 p.m. \\
\hline Temperature $\left({ }^{\circ} \mathrm{C}\right)$ & 24.90 & 29.70 & 31.40 & 27.60 \\
\hline Air relative humidity (\%) & 92.10 & 92.80 & 68.8 & 66.30 \\
\hline Black globe temperature and humidity index & 73.70 & 77.20 & 79.1 & 76.20 \\
\hline Radiant heat load $\left(\mathrm{W} / \mathrm{m}^{2}\right)$ & 551.00 & 558.10 & 553.10 & 547.80 \\
\hline
\end{tabular}

Regarding chewing activity, the lamb breed did not affect the variables. The LC diet increased $(P<0.05)$ the number of ruminated cakes per day (BOL) (Table 4). However, we did not observe an effect $(P>0.05)$ on the interaction between diets and breeds for the $\mathrm{BOL}$, total chew number, and number of chews per bolus (Table 4).

In this study, water intake (WI), water intake from feed (WFI), total water intake (TWI), and chewing time per bolus (CTPB) of lambs showed significant effects on the interaction between diet and breed $(P<0.05)$. Rabo Largo lambs fed LC diets showed lower WI, WFI, and TWI than Santa
Inês lambs, while the latter showed lower CTPB when fed with $\mathrm{HC}$ diets (Table 5).

In general, Rabo Largo lambs had a higher $(P<0.05)$ respiratory rate and rectal temperature. However, higher skin temperatures were observed in Santa Inês lambs fed the $\mathrm{HC}$ diet (Table 6). There was an effect of the interaction between breed and diet $(P<0.05)$ on skin temperature and respiratory rate, whereby Santa Inês lambs fed with LC diets tended to present lower $(P<0.05)$ respiratory frequency (Table 7).

Table 4 Water intake and ingestive behaviour from lamb's breeds fed with experimental diets.

\begin{tabular}{|c|c|c|c|c|c|c|c|c|}
\hline \multirow[b]{2}{*}{ Item } & \multicolumn{2}{|c|}{ Breed (B) } & \multicolumn{2}{|c|}{ Diets $(D)^{1}$} & \multirow[b]{2}{*}{ SEM } & \multicolumn{3}{|c|}{$P$-value } \\
\hline & $\begin{array}{l}\text { Rabo } \\
\text { argo }\end{array}$ & Santa Inês & HC diet & LC diet & & B & D & $\mathrm{B}$ vs D \\
\hline \multicolumn{9}{|l|}{ Water intake } \\
\hline WI (kg/day) & 1.54 & 1.69 & $1.80^{\mathrm{a}}$ & $1.43^{b}$ & 0.086 & 0.306 & 0.014 & 0.006 \\
\hline WFI (kg/day) & $0.10^{\mathrm{B}}$ & $0.12^{\mathrm{A}}$ & $0.13^{a}$ & $0.09^{b}$ & 0.006 & 0.030 & 0.001 & 0.048 \\
\hline TWI (kg/day) & 1.64 & 1.81 & $1.93^{a}$ & $1.52^{\mathrm{b}}$ & 0.089 & 0.252 & 0.008 & 0.005 \\
\hline RWDM (kg/kg) & 2.83 & 2.41 & 2.43 & 2.80 & 0.154 & 0.179 & 0.236 & 0.997 \\
\hline RTWDM (kg/kg) & 2.99 & 2.57 & 2.60 & 2.97 & 0.153 & 0.179 & 0.234 & 0.999 \\
\hline \multicolumn{9}{|c|}{ Time of activities (h/day) } \\
\hline Feeding & 4.07 & 4.04 & $3.58^{b}$ & $4.52^{\mathrm{a}}$ & 0.164 & 0.916 & 0.003 & 0.978 \\
\hline Rumination & 8.73 & 9.13 & $8.29^{b}$ & $9.58^{a}$ & 0.234 & 0.340 & 0.005 & 0.340 \\
\hline Idling & 11.19 & 10.83 & $12.13^{\mathrm{a}}$ & $9.90^{\mathrm{b}}$ & 0.334 & 0.530 & 0.001 & 0.506 \\
\hline TCT & 12.81 & 13.17 & $11.87^{b}$ & $14.10^{\mathrm{a}}$ & 0.334 & 0.530 & 0.001 & 0.507 \\
\hline \multicolumn{9}{|l|}{ Efficiencies (g/h) } \\
\hline $\mathrm{FE}_{\mathrm{DM}}$ & $166.90^{\mathrm{B}}$ & $205.58^{A}$ & $240.5^{a}$ & $131.97^{b}$ & 14.710 & 0.029 & 0.001 & 0.995 \\
\hline $\mathrm{FE}_{\mathrm{NDF}}$ & $75.01^{\mathrm{B}}$ & $92.82^{\mathrm{A}}$ & 90.82 & 78.43 & 4.968 & 0.029 & 0.115 & 0.451 \\
\hline $\mathrm{RE}_{\mathrm{DM}}$ & $68.90^{\mathrm{B}}$ & $86.74^{\mathrm{A}}$ & $97.53^{\mathrm{a}}$ & $58.12 b$ & 4.240 & 0.001 & 0.001 & 0.348 \\
\hline $\mathrm{RE}_{\mathrm{NDF}}$ & $31.67^{\mathrm{B}}$ & $39.60^{A}$ & 36.47 & 34.80 & 1.255 & 0.004 & 0.403 & 0.095 \\
\hline \multicolumn{9}{|l|}{ Chewing } \\
\hline BOL (bolus/day) & 728.76 & 698.27 & $660.68^{b}$ & $766.35^{a}$ & 25.034 & 0.535 & 0.037 & 0.678 \\
\hline $\mathrm{CT}_{\mathrm{PB}}$ (seg/bolus) & 71.49 & 68.29 & 69.89 & 69.89 & 1.470 & 0.210 & 0.998 & 0.020 \\
\hline NTC (chewing/day) & 48568 & 45544 & 44392 & 49720 & 1450.8 & 0.476 & 0.308 & 0.513 \\
\hline $\mathrm{NC}_{\mathrm{PB}}$ (chewing/bolu) & 46.57 & 49.74 & 47.34 & 48.98 & 1.136 & 0.164 & 0.466 & 0.147 \\
\hline
\end{tabular}

WI: water intake; WFI: water from feed intake; TWI: total water intake; RWDM: ratio between water intake and dry matter intake; RTWDM: ratio between total of water intake and dry matter intake. TCT: total chewing time; $\mathrm{FE}_{\mathrm{DM}}$ : feeding efficiency of dry matter; $\mathrm{FE}_{\mathrm{NDF}}$ : feeding efficiency of neutral detergent fibre; REDM: rumination efficiency of dry matter; RENDF: rumination efficiency of neutral detergent fibre; BOL: number of ruminated bolus; $C_{P B}$ : chewing time per bolus; NTC: number total of chewing; $\mathrm{NC}_{\mathrm{PB}}$ : number of chewing per bolus. Averages followed by different letters on the same line, upper case for the breed factor and lower case for the diet factor, did not differ by the Tukey test at $5 \%(P<0.05)$. SEM standard error of means. ${ }^{1} \mathrm{HC}$ diet $=$ diet containing high percentage of concentrate $(700 \mathrm{~g} / \mathrm{kg} \mathrm{DM})$ and $\mathrm{LC}$ diet $=$ diet containing low percentage of concentrate $(300 \mathrm{~g} / \mathrm{kg} \mathrm{DM})$ 


\section{Discussion}

The diet containing a high (700 g/kg DM; HC diet) percentage of concentrate increased water intake (WI) for both breeds (Table 5), which is likely a physiological defence mechanism of the animal to avoid metabolic disorders, such as acidosis, and thus maintain rumen health (Mendes et al 2020).

However, Rabo Largo lambs had lower WI compared to Santa Inês lambs, when both were fed diets containing a low (300 g/kg DM; LC diet) percentage of concentrates. According to Kaliber et al (2016), there is a strong relationship between dry matter intake (DMI) and $\mathrm{WI}$, derived from the amount of energy ingested and the water flow. Thus, the higher WI by animals fed the HC diet could be attributed to the higher DMI (Table 2).

Differences in NDF content between diets (Table 1) may be responsible for the variances in DMI and NDFI (Table 2). NDF is highly correlated with low energy density of the diet, as it increases the fraction that is digestion slowly, and therefore is associated with rumen filling and reduced DM intake (Van Soest 1994).

In this study, the $\mathrm{HC}$ diet (composed of $70 \%$ of grains) promoted a higher concentration of NFC and reduced NDF (Table 1). NFC-fermenting microorganisms grow faster than those that ferment fibre (Russel et al 1992). Therefore, the rate of degradability and passage increased with the removal of food in the rumen.

The DMI increased until there was satiety of animals by energy density signalled by higher production of shortchain fatty acids (SCFA), especially propionate. This behaviour has already been observed in studies on lambs (Sousa et al 2012; Silva et al 2015; Nascimento et al 2020).

Due to the larger size, the Santa Inês lambs presented higher DMI; however, when the body weight, was adjusted for, there was no effect of the breed (Table 2), proving that both breeds have adequate DMI/BW (2.5-3.0\% by NRC, 2007), even when confined in severe microclimatic conditions. These results are noteworthy in that both races, from the point of view of feed ingestion, are adapted to the semi-arid climate conditions characteristic of Northeastern Brazil (Peixoto et al 2021).
Lambs fed the LC diet had longer feeding and rumination times (Table 4), even when they had lower DMIs (in $\mathrm{g} /$ day and\% BW). A possible explanation is that fibre requires more time to be fermented, causing a lower energy density (Silva et al 2015). This requires that the animal, in addition to requiring more feeding time to meet its nutritional demands, increasing its physical filling, causing less DMI (Perazzo et al 2017), but also increasing the rumination time and consequently the quantity of ruminated boli (Nascimento et al 2020).

The $\mathrm{HC}$ diet decreased the time spent on feeding due to the high energy density of the diet, amplifying ruminal degradability and passage rate, allowing lambs to spend less feeding time to meet their nutritional needs (Ferro et al 2019). The smaller size of particulate matter and higher density of the feed particulate of the concentrate when compared to the forage, caused the microorganisms to have greater access to the feed, as well faster growth and replication of the NFC-fermenting microorganisms (Mazza et al 2020), thus giving the lambs a greater supply of SCFA.

The greater intake in shorter feeding time provided to the $\mathrm{HC}$ diets improved DM efficiencies in feeding and rumination, since the Santa Inês lambs had larger size and presented greater DMI, and even without affecting the feeding time, Santa Inês lambs showed greater DM and NDF efficiencies of feeding and rumination.

The high NDF provided by the content, LC diet increased the rumination time and, consequently, the number of boluses (Bürger et al 2000). Chewing reduces the size of fibrous particles to increase the contact surface for ruminal microorganisms, thereby enhancing microbial activity, in addition to facilitating the degradation and use of nutrients (Perazzo et al 2017).

The values of the black globe-humidity index (BGHI) were higher in the 14:00 readings, were higher (79.1;Table 3). Therefore, these indications of $\mathrm{BGHI}$ are considered promoters of severe heat stress in sheep (Habeeb et al 2018). This greater thermal radiation received during the hours considered to be have the highest temperatures, between 11:00 and 15:00, can reduce thyroid hormones (T3 and T4) by inhibiting feed intake (Koluman and Daskiran 2011).

Table 5 Averages of water intake variables and chewing time per bolus $\left(\mathrm{CT}_{\mathrm{PB}}\right)$ from lambs in the interaction between breeds and diets.

\begin{tabular}{|c|c|c|c|c|c|}
\hline \multirow{2}{*}{ Item } & \multirow{2}{*}{ Breeds (B) } & \multicolumn{2}{|c|}{ Diets (D) ${ }^{1}$} & \multirow{2}{*}{ SEM } & \multirow{2}{*}{$\frac{P \text {-value }}{B \text { vs D }}$} \\
\hline & & $\mathrm{HC}$ diet & LC diet & & \\
\hline \multirow{2}{*}{ WI (kg/day) } & Rabo Largo & $1.94^{\mathrm{Aa}}$ & $1.15^{\mathrm{Bb}}$ & \multirow{2}{*}{0.086} & \multirow{2}{*}{0.006} \\
\hline & Santa Inês & $1.67^{\mathrm{Aa}}$ & $1.72^{\mathrm{Aa}}$ & & \\
\hline \multirow{2}{*}{ WFI (kg/day) } & Rabo Largo & $0.13^{\mathrm{Aa}}$ & $0.07^{\mathrm{Bb}}$ & \multirow{2}{*}{0.006} & \multirow{2}{*}{0.048} \\
\hline & Santa Inês & $0.13^{\mathrm{Aa}}$ & $0.11^{\mathrm{Ab}}$ & & \\
\hline \multirow{2}{*}{ TWI (kg/day) } & Rabo Largo & $2.07^{\mathrm{Aa}}$ & $1.22^{\mathrm{Bb}}$ & \multirow{2}{*}{0.089} & \multirow{2}{*}{0.005} \\
\hline & Santa Inês & $1.79^{\mathrm{Aa}}$ & $1.83^{\mathrm{Aa}}$ & & \\
\hline \multicolumn{6}{|l|}{ Chewing } \\
\hline \multirow{2}{*}{$\mathrm{CT}_{\mathrm{PB}}$ (seg/bolus) } & Rabo Largo & $74.59^{A a}$ & $68.40^{\mathrm{Aa}}$ & \multirow{2}{*}{1.470} & \multirow{2}{*}{0.020} \\
\hline & Santa Inês & $65.20^{\mathrm{Ba}}$ & $71.38^{\mathrm{Aa}}$ & & \\
\hline
\end{tabular}

WI: water intake; WFI: water from feed intake; TWI: total water intake; CTPB: chewing time per bolus. Averages followed by different letters on the same line, upper case for the breed factor and lower case for the diet factor, did not differ by the Tukey test at $5 \%(P<0.05)$. SEM standard error of means. ${ }^{1} \mathrm{HC}$ diet $=$ diet containing high percentage of concentrate $(700 \mathrm{~g} / \mathrm{kg} \mathrm{DM})$ and LC diet = diet containing low percentage of concentrate $(300 \mathrm{~g} / \mathrm{kg} \mathrm{DM})$ 
The assessment of the impact of heat stress on the animal is essential for associating the BGHI with physiological parameters. In this study, the skin temperature (ST) was affected by the ambient temperature (Table 6), which by radiation and convection can trigger physiological mechanisms of sweating and vasodilation (Machado et al $2020 b)$. When these mechanisms are not fully effective in reducing ST, the rectal temperature can also be elevated by both the aforementioned and other factors related to internal heat resulting from digestive processes (mainly ruminal fermentation), thus causing the animal to increase heart and respiratory rates for heat dissipation (Eustáquio Filho et al 2011; Peixoto et al 2021).

Santa Inês lambs obtained the highest mean ST (Table 6) due to their greater body surface when compared to Rabo Largo lambs. In addition, the colour of the pelage influenced the result since the Santa Inês lambs in this study had black pelage, and Rabo Largo lambs were red (Souza-Junior et al 2018). McManus et al (2020) claimed that black pelage absorbs greater thermal radiation, and thus, is more susceptible to thermal stress when compared to animals with red, yellow, or white pelage.

The HC diet presented the highest average physiological parameters since animals fed with this diet had higher DMIs. This diet is more quickly fermentable with a caloric increase in the body, causing greater water intake to dissipate the high concentration of SCFA and heat (Machado et al 2020b).
According to McManus et al (2020), when sheep are subjected to heat stress, there is an increase in skin temperature due to the difficulty in dispersing heat. These animals use thermoregulatory mechanisms, such as increased respiratory and heart rates, allowing the animal to adapt to environmental conditions. Such mechanisms cause energy expenditure and can reduce feeding and rumination activities, therefore reducing performance (Santos et al 2019).

Sheep reared in covered environments were classified based on their respiratory rate (RR, breaths/minute) to determine the degree of heat stress: 40-60 low, 60-80 medium-high, $80-120$ high, and above 200 is considered severe stress (Silanikove 2000). The animals in this study obtained an average of 64 breaths per minute, classified as medium-high stress conditions.

The increase in RR is one of the main physiological mechanisms used to dissipate internal heat, which is associated with vasodilation and promotes sweating and/or evapotranspiration in homeothermic organisms (Leite et al 2019). An accelerated and constant RR for several hours can interfere with the daily activities of the animal, as they attempt to dissipate the endogenous heat, which increases the energy spent (Lima et al 2019) and inhibits activities such as feeding and rumination, consequently decreasing the animal's performance (Machado et al 2020a).

Table 6 Physiological parameters from lamb's breeds fed with diets containing high (HC) and low (LC) concentrate.

\begin{tabular}{|c|c|c|c|c|c|c|c|c|}
\hline \multirow{2}{*}{ Item } & \multicolumn{2}{|c|}{ Breed (B) } & \multicolumn{2}{|c|}{ Diets (D) } & \multirow{2}{*}{ SEM } & \multicolumn{3}{|c|}{$P$-value } \\
\hline & Rabo Largo & Santa Inês & $\mathrm{HC}$ diet & LC diet & & $B$ & $\mathrm{D}$ & $\mathrm{B}$ vs D \\
\hline Skin Temperature $\left({ }^{\circ} \mathrm{C}\right)$ & $34.51^{B}$ & $34.77^{A}$ & $34.89^{a}$ & $34.38^{b}$ & 0.126 & 0.001 & 0.001 & 0.013 \\
\hline Rectal Temperature $\left({ }^{\circ} \mathrm{C}\right)$ & $39.32^{\mathrm{A}}$ & $38.01^{\mathrm{B}}$ & $39.33^{a}$ & $38.89^{b}$ & 0.052 & 0.001 & 0.001 & 0.775 \\
\hline Respiratory rate (breaths/min) & $74.00^{\mathrm{A}}$ & $55.00^{\mathrm{B}}$ & $77.00^{\mathrm{a}}$ & $52.00^{b}$ & 1.895 & 0.001 & 0.001 & 0.002 \\
\hline
\end{tabular}

Averages followed by different letters on the same line, upper case for the breed factor and lower case for the diet factor, did not differ by the Tukey test at $5 \%(P<0.05)$. SEM standard error of means. ${ }^{1} \mathrm{HC}$ diet $=$ diet containing high percentage of concentrate $(700 \mathrm{~g} / \mathrm{kg} \mathrm{DM})$ and $\mathrm{LC}$ diet $=$ diet containing low percentage of concentrate $(300 \mathrm{~g} / \mathrm{kg} \mathrm{DM})$

Table 7 Averages of skin temperature (ST) and respiratory rate (RR) from lambs in the interaction between breeds and diets.

\begin{tabular}{|c|c|c|c|c|c|}
\hline \multirow{2}{*}{ Item } & \multirow{2}{*}{ Breeds (B) } & \multicolumn{2}{|c|}{ Diets $(D)^{1}$} & \multirow{2}{*}{ SEM } & \multirow{2}{*}{$\begin{array}{l}P \text {-value } \\
\text { B vs D }\end{array}$} \\
\hline & & $\mathrm{HC}$ diet & LC diet & & \\
\hline \multirow{2}{*}{ Skin temperature $\left({ }^{\circ} \mathrm{C}\right)$} & Rabo Largo & $34.68^{\text {ва }}$ & $34.33^{\mathrm{Ab}}$ & \multirow{2}{*}{0.126} & \multirow{2}{*}{0.013} \\
\hline & Santa Inês & $35.10^{\mathrm{Aa}}$ & $34.43^{\mathrm{Ab}}$ & & \\
\hline \multirow{2}{*}{ Respiratory rate (breaths/min) } & Rabo Largo & $90.32^{\mathrm{Aa}}$ & $58.44^{\mathrm{Ab}}$ & \multirow{2}{*}{1.895} & \multirow{2}{*}{0.002} \\
\hline & Santa Inês & $64.03^{\mathrm{Ba}}$ & $46.41^{\mathrm{Bb}}$ & & \\
\hline
\end{tabular}

Averages followed by different letters on the same line, upper case for the breed factor and lower case for the diet factor, did not differ by the Tukey test at $5 \%(P<0.05)$. SEM standard error of means. ${ }^{1} \mathrm{HC}$ diet $=$ diet containing high percentage of concentrate $(700 \mathrm{~g} / \mathrm{kg} \mathrm{DM})$ and $\mathrm{LC}$ diet $=$ diet containing low percentage of concentrate (300 $\mathrm{g} / \mathrm{kg} \mathrm{DM})$

Rabo Largo lambs had higher averages for RR in both diets (Table 7) and lower water intake (Table 4), which can be explained by the accumulation of body fat, especially in the rump and breast regions. This accumulation of fat promotes thermal insulation which can compromise heat dissipation (Souza et al 2015). Generally, these animals use this energy reserve of fat to compensate in periods of water and nutrition deficit. At higher temperatures, these energy reserves tend 
to decrease, making these animals more adapted and rustic to semi-arid environments.

This energy reserve is used when a decrease in rumen bacterial activity (Bernabucci et al 2009) and a lower rate of passage at the time of heat stress (Christopherson and Kennedy 1983) are signalled through metabolic changes, and high temperatures can also cause an increase in water loss through evaporation and sweating (Bhattacharya and Hussain 1974; Costa et al 1992). Animals tend to have a greater amount of endogenous water from lipolysis, thus reducing the need for water intake by fat-tailed animals when consuming low-quality diets, corroborating the results found.

\section{Conclusions}

High-concentrate diets negatively affect the thermoregulation of lambs in feedlots. Between the two evaluated breeds, Santa Inês lambs had more interesting thermoregulation and feed efficiency characteristics for feedlots under the micrometeorological conditions of the study.

\section{Conflict of Interest}

The authors declare that there is no conflict of interest.

\section{Funding}

This study was performed as a result of scholarship research funded by the Coordination for the Improvement of Higher Education Personnel - Brazil (CAPES) - Finance Code 001, the National Council for Scientific and Technological Development (CNPq-Brazil), and the Foundation for Research Support of the State of Maranhão - Brazil (FAPEMA).

\section{References}

AOAC (1990) Association of Official Analytical Chemists. Official methods of analyses of the AOAC. 15 ed. Washington, assoc. Off. Agric. Chem., pp 11051106.

Azevedo RA, Rufino LMA, Santos ACR, Ribeiro-Junior CS, Rodriguez NM, Geraseev LC (2013) Ingestive behavior of lambs fed with macauba meal. Arquivo Brasileiro de Medicina Veterinária e Zootecnia 65:490-496.

Bernabucci U, Lacetera N, Danieli PP, Bani P, Nardone A, Ronchi B (2009) Influence of different periods of exposure to hot environment on rumen function and diet digestibility in sheep. International Journal of Biometeorology 53:387-395.

Bezerra HFC, Santos EM, Oliveira JS, Carvalho GGP, Silva F, Cassuce M, Perazzo AF, Zanine AM, Pinho RMA (2019) Performance and ruminal parameters of Boer crossbred goats fed diets containing crude glycerin. Animals 9:1-10.

Bhattacharya AN, Hussain F (1974) Intake and utilization of nutrients in sheep fed different levels of roughage under heat stress. Journal of Animal Science 38:877-886.

Borges JO, Silva APV, Carvalho RA (2018) Conforto térmico de ovinos da raça Santa Inês confinados com dietas contendo três níveis de inclusão de concentrado. Boletim da Indústria Animal 75:01-07.

Buffington DE, Collazoarocho A, Canton GH, Pitt D (1981) Black globehumidity index (BGHI) as comfort equation for dairy cows. Transactions of the ASAE 24:711-714.

Bürger PJ, Pereira JC, Queiroz AC, Silva JFC, Valadares-Filho SC, Cecon PR, Casali ADP (2000) Ingestive Behavior in Holstein Calves Fed Diets with Different Concentrate Levels. Revista Brasileira de Zootecnia 16:236-242.
Carvalho GGP, Garcia R, Pires AJV, Detmann E, Ribeiro LSO, Chagas DMT, Silva RR, Pinho BD (2011) Ingestive behavior in goats fed diets containing sugar cane treated with calcium oxide. Revista Brasileira de Zootecnia 40:1767-1773.

Costa MJRP, Silva RG, Souza RC (1992) Effect of air temperature and humidity on ingestive behaviour of sheep. International Journal of Biometeorology $36: 218-222$.

Christopherson RJ, and Kennedy PM (1983) Effect of the thermal environment on digestion in ruminants. Canadian Journal of Animal Science 63:477-496.

Detmann E, Souza MA, Valadares Filho SC, Queiroz AC, Berchielli TT, Saliba EOS, Cabral LS, Pina DS, Ladeira MM, Azevedo JAG (2012) Métodos para análise de alimentos (Methods for food analysis) - INCT - Ciência Animal, (Suprema, Visconde do Rio Branco).

Esmay, ML (1969) Principles of animal environment. Westport: AVI Publishing; pp 325.

Eustáquio-Filho A, Teodoro SM, Chaves MA, Santos PEF, Dos Silva MWR, Da Murta RM, Carvalho GP, De Souza LEB (2011) Thermal comfort zone of Santa Ines sheep based on physiological responses. Revista Brasileira de Zootecnia 40:1807-1814.

Ferro MM, Zanine AM, Jesus DF, Souza AL, Geron LV, Castro WJR, Parente HN, Parente MOM (2019) Ingestion behaviour of feedlot sheep fed on bean processing residue. International Journal of Agriculture \& Biology 21:164170.

Habeeb AA, Gad AE, Atta MA (2018) Temperature-humidity indices as indicators to heat stress of climatic conditions with relation to production and reproduction of farm animals. International Journal of Biotechnology and Recent Advances 1:35-50.

Johnson TR, Combs DK (1991) Effects of prepartum diet, inert rumen bulk, and dietary polyethylene glycol on dry matter intake of lactating dairy cows. Journal Dairy Science 74:933-944.

IBGE. Brazilian Institute of Geography and Statistics. 2019. Flock of sheep in Brazil (in Portuguese). Rio de Janeiro: IBGE. Available https://ainfo.cnptia.embrapa.br/digital/bitstream/item/202493/1/CNPC2019-Boletim-CI-n9.pdf. Accessed on: January, 102021.

Kaliber M, Koluman N, Silanikove N (2016) Physiological and behavioral basis for the successful adaptation of goats to severe water restriction under hot environmental conditions. Animal 10:82-88.

Koluman N, Daskiran I (2011) Effects of ventilation of the sheep house on heat stress, growth and thyroid hormones of lambs. Tropical Animal Health and Production 43:1123-1127.

Leite PG, Marques JI, Furtado DA, Lopes-Neto JP, Souza BB, Nascimento JWB (2019) Ethology, physiological, and ingestive responses of sheep subjected to different temperatures and salinity levels of water. International Journal of Biometeorology 63:1091-1098.

Lima LR, Souza-Junior JBF, Duarte LM, Mendes MSP, Barbosa-Filho JAD, Gadelha CRF, Pimentel PG (2019) Thermophysiological indicators of lambs during pre-slaughter handling. Biological Rhythm Research 50:553-563.

Machado NAF, Parente MOM, Parente HN, Zanine AM, Moreira-Filho MA, Cunha IAL, Sousa JMS, Anjos LF, Ferreira DJ, Araújo JS (2020a) The physiological response, feeding behaviour and water intake of feedlot lambs supplemented with babassu oil or buriti oil. Biological Rhythm Research 51:213-224.

Machado NAF, Barbosa-Filho JAD, Oliveira KPL, Parente MOM, Siqueira J, Pereira AM, Santos ARD, Sousa JMS, Rocha KS, Viveiros KKS, Costa CS (2020b) Biological rhythm of goats and sheep in response to heat stress. Biological Rhythm Research 51:1044-1052.

Machado NAF, Da Costa LB, Barbosa-Filho JAD, Oliveira KPL, Sampaio LC, Peixoto MSM, Damasceno FA (2021a) Using infrared thermography to detect subclinical mastitis in dairy cows in compost barn systems. Journal Thermal Biology 97:102881.

Machado NAF, Martin JE, Barbosa-Filho JAD, Dias CTS, Pinheiro DG, Oliveira $\mathrm{KPL}$, Souza-Junior JBF (2021b) Identification of trailer heat zones and associated heat stress in weaner pigs transported by road in tropical 
climates. Journal Thermal Biology 97:102882.

Maurya VP, Sejian V, Kumar D, Naqvi SMK (2019) Impact of heat stress, nutritional stress and their combinations on the adaptive capability of Malpura sheep under hot semi-arid tropical environment. Journal of Animal Behaviour and Biometeorology 7(1):17-23.

Mazza PHS, Jaeger SMPL, Silva FL, Barbosa AM, Nascimento TVC, Hora DIC, Júnior Silva JM, Bezerra LR, Oliveira RL (2020) Effect of dehydrated residue from acerola (Malpighia emarginata DC.) fruit pulp in lamb diet on intake, ingestive behavior, digestibility, ruminal parameters and $\mathrm{N}$ balance. Livestock Science 233:103938.

McManus CM, Faria DA, Lucci CM, Louvandini H, Pereira SA, Paiva SR (2020) Heat stress effects on sheep: Are hair sheep more heat resistant?. Theriogenology 155:157-167.

Mendes JAC, Parente MOM, Parente HN, Zanine AM, Jesus DF, Moreira-Filho MA, Cunha IAL, Landin AV, Rocha KS (2020) Performance, ingestive behavior and cost of production of finishing lambs fed nonforage diets 51:460-470.

Nascimento CO, Santos SA, Pina DS, Tosto MSL, Pinto LFB, Eiras DN, Assis DYC, Perazzo AF, Araújo MLGML, Azevêdo JAG, Mourão GB, Carvalho GGP (2020) Effect of roughage-to-concentrate ratios combined with different preserved tropical forages on the productive performance of feedlot lambs. Small Ruminant Research 182:15-21.

NRC - National Research Council (2007). Nutrient requirements of dairy cattle. $1^{\circ}$.ed. Washington: D.C

Parente MOM, Rocha KS, Bessa JBR, Parente HN, Zanine AM, Machado NAF, Lourenço Júnior JB, Bezerra LR, Landin AV, Alves SP (2020) Effects of the dietary inclusion of babassu oil or buriti oil on lamb performance, meat quality and fatty acid composition. Meat Science 160:107971.

Perazzo AF, Homem-Neto SP, Ribeiro OL, Santos EM, Carvalho GGP, Oliveira JS, Bezerra HFC, Campos FS, Freitas-Junior JE (2017) Intake and ingestive behavior of lambs fed diets containing ammoniated buffel grass hay. Tropical Animal Health and Production 49:717-724.

Peixoto MSM, Barbosa-Filho JAD, Machado NAF, Viana VSS, Costa JFM (2021) Thermoregulatory behavior of dairy cows submitted to bedding temperature variations in Compost barn systems. Biological Rhythm Research 52:11201129.

Polli VA, Restle J, Senna DB, Almeida SRS (1996) Aspectos relativos à ruminação de bovinos e bubalinos em regime de confinamento. Revista Brasileira de Zootecnia 25:987-993.

Roberto JVB, Souza BB (2011) Fatores ambientais, nutricionais e de manejo e índices de conforto térmico na produção de ruminantes no semiárido. Revista Verde de Agroecologia e Desenvolvimento Sustentavel 6:8-13.

Russel JB, O'Connor JD, Fox DG, Van Soest PJ, Sniffen CJ (1992) A net carboydrate and protein system for evaluing cattle diets: Ruminal Fermentation. Journal of Animal Science 70:3551- 3561.

Santos ARD, Parente HN, Machado NAF, Araújo JS, Ferreira DJ, Rocha KS, Anjos LF, Portela YN, Sousa MN, Zanine AM, Nascimento TVC, Parente MOM
(2019) The physiological response, feeding behaviour and water intake of goat kids fed diets with increasing levels of babassu mesocarp flour. Biological Rhythm Research 50:01-13.

Santos MM, Azevedo MA, Costa LAB, Silva-Filho FP, Modesto EC, Lana Â MQ (2011) Comportamento de ovinos da raça Santa Inês, de diferentes pelagens, em pastejo. Acta Scientiarum. Animal Science 33:287-294.

Seixas L, Melo CB, Tanure CB, Peripolli V, McManus C (2017) Heat tolerance in Brazilian hair sheep. Asian-Australasian Journal of Animal Sciences 30:593601.

Silanikove N (2000) Effects of heat stress on the welfare of extensively managed domestic ruminants. Livestock Production Science 67:01-18.

Silva AMA, Sobrinho AS, Trindade IACM, Resende KTD, Bakke OA (2004) Food intake and digestive efficiency in temperate wool and tropic semi-arid hair lambs fed different concentrate: forage ratio diets. Small Ruminant Research 55:107-115.

Silva GA, Souza BS, Silva EMN (2015a) Adaptability of sheep and strategies to minimize the effects of climate in tropical regions. Journal of Animal Behaviour and Biometerology 3:20-27.

Silva TC, Pereira OG, Agarussi MCN, Silva VP, Silva LD, Cardoso LL, Ribeiro KG, Valadares-Filho SC (2015b) Stylosanthes cv. Campo Grande silage with or without concentrate in sheep diets: nutritional value and ruminal fermentation. Small Ruminant Research 126:34-39.

Silva TM, Oliveira RL, Nascimento Júnior NG, Pellegrini CB, Trajano JS, Rocha TC, Bezerra LR, Borja MS (2016) Ingestive behavior and physiological parameters of goats fed diets containing peanut cake from biodiesel. Tropical Animal Health and Production 48:59-66.

Sniffen CJ, O’Connor JD, Van Soest PJ, Fox DG, Russell JB (1992) A net carbohydrate and protein system for evaluating cattle diets: II. Carbohydrate and protein availability. Journal of Animal Science 70:3562-3577.

Sousa WH, Cartaxo FQ, Costa RG, Cezar MF, Cunha MDGG, Pereira-Filho JMP Michel N (2012) Biological and economic performance of feedlot lambs feeding on diets with different energy densities. Revista Brasileira de Zootecnia 41:1285-1291.

Souza-Junior JBF, Queiroz JPAF, Santos VJS, Dantas MRT, Lima RN, Oliveira PL, Macedo-Costa LL (2018) Cutaneous evaporative thermolysis and hair coat surface temperature of calves evaluated with the aid of a gas analyzer and infrared thermography. Computers and Electronics in Agriculture 150:222226.

Van Soest PJ, Robertson JB, Lewis BA (1991) Methods for dietary fiber, neutral detergent fiber, and nonstarch polysaccharides in relation to animal nutrition. Journal of Dairy Science 74:3583-3597.

Van Soest PJ (1994) Nutritional ecology of the ruminant, 2.ed. Ithaca, New York (USA): Cornell University Press.

Wilkes MJ, Hynd PI, Pitchford WS (2012) Damara sheep have higher digestible energy intake than Merino sheep when fed low-quality or highquality feed. Animal Production Science 52:30-34. 